\title{
The effectiveness of using visualization tools and forms in distance learning
}

\section{A eficácia do uso de ferramentas e formulários de visualização no ensino à distância}

\section{La eficacia del uso de herramientas y formularios de visualización en el aprendizaje a distancia}

\begin{abstract}
Anatoly Nikolaevish Andreev1 (D), Olga Viktorovna Emtseva1 (D), Ekaterina Sergeevna Babkina² (D), Valeriy Nikolaevich Dolzhenkov ${ }^{3}$ (D), Nina Valentinovna Kudryashova ${ }^{4}$
\end{abstract}

\footnotetext{
${ }^{1}$ K.G. Razumovcky Moscow State University of Technologies and Management (the First Cossack University), Moscow, Russia.

2 Pacific National University, Khabarovsk, Russia.

${ }^{3}$ Moscow Aviation Institute (National Research University), Moscow, Russia.

${ }^{4}$ Russian State Social University, Moscow, Russia.
}

Corresponding author:

Anatoly Nikolaevish Andreev

Email: anandreev58@mail.ru

How to cite: Andreev, A. N., Emtseva, O. V., Babkina, E. S., Dolzhenkov, V. N., \& Kudryashova, N. V. (2021). The effectiveness of using visualization tools and forms in distance learning. Revista Tempos e Espaços em Educação, 14(33), e16053. http://dx.doi.org/10.20952/revtee.v14i33.16053

\begin{abstract}
The purpose of the article is to comprehensively consider the concept of visualization, which is one of the main factors of effective learning of educational material, as well as to analyze the possibilities of using visualization in distance learning. The article shows the relevance of visualization of distance education, describes visualization technologies as a tool for improving the effectiveness of distance learning, defines the essence of visualization in education, finds out the possibilities of using visualization to ensure the professional training of future specialists in the course of distance learning of academic disciplines, as well as considers the visualization tools used in students' distance learning. Based on an empirical study of using visualization in the course of distance learning of the "Pedagogical Skills" course, the formedness of the cognitive and operational components of students' educational activities was evaluated. This allowed concluding that using contemporary visualization technologies in the educational process creates prerequisites for improving the quality and effectiveness of training, acts as a key factor in improving the effectiveness of the educational process. Visualization allows solving a set of pedagogical problems, such as making the complicated educational material of various disciplines understandable, accessible for awareness, without reducing the level of its scientific character, creating conditions
\end{abstract}


for informal assimilation of the training content by learners, contributing acquisition of deep, systematic knowledge, and so on.

Keywords: Visualization. Visualization Tools. Visualization Forms. Distance Learning. Distance Education.

\section{RESUMO}

O objetivo do artigo é considerar de forma abrangente o conceito de visualização, que é um dos principais fatores para a aprendizagem efetiva de materiais educacionais, bem como analisar as possibilidades de utilização da visualização na educação a distância. $O$ artigo mostra a relevância da visualização na educação a distância, descreve as tecnologias de visualização como uma ferramenta para melhorar a eficácia da educação a distância, define a essência da visualização na educação, descobre as possibilidades do uso da visualização para garantir a formação profissional de futuros especialistas na área. curso de EAD de disciplinas acadêmicas, bem como considerando as ferramentas de visualização utilizadas na EAD dos alunos. Com base no estudo empírico do uso da visualização no curso de educação a distância do curso "Habilidades Pedagógicas", avaliou-se a formação dos componentes cognitivos e operacionais das atividades educacionais dos alunos. Isso permitiu concluir que o uso de tecnologias contemporâneas de visualização no processo educacional cria pré-requisitos para a melhoria da qualidade e eficácia do treinamento, atua como um fator chave na melhoria da eficácia do processo educacional. A visualização permite resolver um conjunto de problemas pedagógicos, como tornar o complicado material didáctico de várias disciplinas compreensíveis, acessível à sensibilização, sem reduzir o nível do seu carácter científico, criando condições para a assimilação informal dos conteúdos formativos pelos formandos, contribuindo para a aquisição de aprofundamento, conhecimento sistemático e assim por diante.

Palavras-chave: Visualização. Ferramentas de visualização. Formulários de visualização. Ensino à distância. Educação a Distância.

\section{RESUMEN}

El propósito del artículo es considerar de manera integral el concepto de visualización, que es uno de los principales factores del aprendizaje efectivo del material educativo, así como analizar las posibilidades de utilizar la visualización en el aprendizaje a distancia. El artículo muestra la relevancia de la visualización de la educación a distancia, describe las tecnologías de visualización como una herramienta para mejorar la efectividad del aprendizaje a distancia, define la esencia de la visualización en la educación, descubre las posibilidades del uso de la visualización para asegurar la formación profesional de futuros especialistas en el curso de aprendizaje a distancia de disciplinas académicas, así como también considera las herramientas de visualización utilizadas en el aprendizaje a distancia de los estudiantes. Con base en un estudio empírico del uso de la visualización en el curso de educación a distancia del curso "Habilidades Pedagógicas", se evaluó la conformación de los componentes cognitivos y operativos de las actividades educativas de los estudiantes. Esto permitió concluir que el uso de tecnologías de visualización contemporáneas en el proceso educativo crea prerrequisitos para mejorar la calidad y efectividad de la formación, actúa como factor clave para mejorar la efectividad del proceso educativo. La visualización permite resolver un conjunto de problemas pedagógicos, como hacer comprensible el complicado material educativo de diversas disciplinas, accesible a la conciencia, sin reducir el nivel de su carácter científico, creando condiciones para la asimilación informal de los contenidos formativos por parte de los educandos, contribuyendo a la adquisición de conocimientos profundos., conocimiento sistemático, etc.

Palabras clave: Visualización. Herramientas de visualización. Formularios de visualización. La educación a distancia. Educación a distancia.. 


\section{INTRODUCTION}

The rapid penetration of ICTs into human life and the overload by information flows require contemporary education to adopt new technologies, change the ways of teaching, and presenting educational information, and implementation of new learning technologies that would be effective in the current context (Vinichenko et al., 2018; Rabadanova et al., 2020).

In the contemporary world, the role of complex communication skills, expert assessment, and system thinking as a component of a specialist's professional development is increasing. One of the most effective means of developing these skills is using visualization in the upbringing and educational process and in the course of managing an educational institution using the capabilities of the modern information environment (Wang, Katkhanova, 2020). Visualization tools provide an opportunity for teachers, students, listeners, and administrators to present visual qualitative and quantitative models of the studied processes and phenomena, to understand their relationship, to investigate the influence of various factors, and to present the development of the studied phenomena and processes in a visual form.

The discrepancy between the growing amount of information and the amount of study time is the task that today's teachers are trying to solve. Due to the increase in the absolute volume of information, the use of traditional methods of working with information becomes unproductive. Therefore, in the educational process, it is advisable to use the "compression" and "folding" techniques of verbal educational information. This will allow not only to clearly organizing the educational process, focusing the student's attention on the key points of the discipline but also contributing to the formation of the ability to perform logical operations, instilling to the student a skill of being organized during their work with educational information.

The expediency of using visualization of educational information is dictated, first of all, by the need to present it in a form that best meets the new needs of the contemporary generation of students. Psychologists and cultural scientists, describing this generation, note about a new culture of information perception, about a new type of thinking - the so-called clip thinking, which is formed as a response to the rapid growth of information flow, mainly in visual form, to the high fragmentation, great diversity and complete heterogeneity of incoming information. The features of such thinking, as V.S. Bratash (2020) notes, are the ability to quickly switch between disparate semantic fragments, high speed of information processing, a preference to perceive information in a figurative form, but at the same time the inability to perceive linear, homogeneous information, including long book texts. Bratash believes that such thinking is more consistent with the modern information environment.

Thus, considering the features of the contemporary digital generation, which has formed fundamentally different ways of receiving, perceiving, and assimilating information, changed the ways of thinking and understanding in comparison with previous generations, rejected verbal ways of presenting material, practicing clip thinking aimed at a clear visual image, scientists consider it appropriate to take into account these features and provide an opportunity to present and assimilate educational material in a convenient visual form (Kukhta, 2004; Gilbert, 2005).

The visualization of educational information is based on the use of the features of the visual system and the innate ability of the human brain to work effectively with visual images. The human visual system is dominant, not only because it is the most important source of information about the surrounding world, but also because it plays the role of an internal communication channel between all analyzers, is a functional organ - a signal converter (Roem, 2012). Information visualization allows translating educational information received through different channels of perception into a visual form, which increases the speed of processing and assimilation of the material due to the most effective ways of working with information (Mathai, Ramadas, 2009).

The new information and educational environment of contemporary universities forms fundamentally new roles of the educational process subjects. The teacher acts as an organizer, 
facilitator, while the student (listener) performs the role of a researcher. The joint creation of visual diagrams involves the creative interaction of the teacher and the student and can bring to life new products of joint activities (Ovchinnikova, 2015).

Using visualization technologies contributes to solving one of the main problems of contemporary education, namely, stimulating interest in learning and developing cognitive interest, since traditional textbooks do not fully meet the requirements of "digital natives", who strive to do everything at once, quickly abstracting their minds from uninteresting things.

In recent years, visualization tools have evolved from tools for solving various kinds of problems to powerful tools for studying social phenomena and technical problems. They are successfully used in industries such as system analysis, design automation, organization of computing facilities, and computer networks.

\section{LITERATURE REVIEW}

In the scientific literature, there are various approaches to the concept of visualization (Table 1).

Table 1. Approaches to the concept of "visualization"

\begin{tabular}{|l|l|}
\hline Source & Concept \\
\hline (Manko, 2009) & $\begin{array}{l}\text { Data output to ensure maximum ease of understanding by the user of, for example, the } \\
\text { processing results of a scientific experiment }\end{array}$ \\
\hline Zaslavskaya, 2019) & $\begin{array}{l}\text { Condensing the mental content into the visual image; being perceived, the image can } \\
\text { be deployed to support adequate mental and practical actions }\end{array}$ \\
\hline (Zelyazny, 2012) & $\begin{array}{l}\text { The method of capturing and transmitting information, which not only complements } \\
\text { but also creates an alternative to verbal and written communication }\end{array}$ \\
\hline (Dodero et al., 2010) & $\begin{array}{l}\text { Any method of providing observable reality, while the result of visualization or visual } \\
\text { model is any construction that is perceived visually and simulates the essence of the } \\
\text { object of knowledge }\end{array}$ \\
\hline
\end{tabular}

According to the classification of G.K. Selevko (1998), pedagogical technology using visualization is classified as a concentrated learning technology. Therefore, according to scientists, the data visualization functions include:

- compact presentation of educational material, which allows increasing the information saturation of the educational process;

- concentrated presentation of the educational material in a visible form while preserving its semantic completeness;

- helping to reduce the time and energy spent by students on the perception and understanding of a large volume of educational material;

- supporting for a high rate of learning by reducing its inefficient or ineffective phases;

- promoting the rational organization of educational and cognitive activities of students through its structuring and algorithmization (Pervushina, 2013).

Based on the analysis of the scientific literature (Abramova, Voronina, Portsev, 2010; Lopuga, 2012; Glizburg, Zykova, 2016), Table 2 shows the most common forms of visualization of educational information. 
Table 2. Analysis of the main approaches to the visualization forms of educational information

\begin{tabular}{|l|l|l|}
\hline No & Visualization form & The contents of the form \\
\hline 1 & $\begin{array}{l}\text { Supporting synopsis } \\
\text { (supportive signal list) }\end{array}$ & $\begin{array}{l}\text { Conditional short abstract, which represents a clear design, replacing the system of facts, } \\
\text { concepts, ideas, as interrelated elements of a part of the training material }\end{array}$ \\
\hline 2 & Flowcharts & $\begin{array}{l}\text { The rigid structure of the depicted material, characterized by pronounced spatial and/or } \\
\text { temporal algorithm }\end{array}$ \\
\hline 3 & Flowgraphs & $\begin{array}{l}\text { Structure of educational material, which is divided into individual elements and defines } \\
\text { to the internal logical connection between them using connecting and directional lines }\end{array}$ \\
\hline 4 & Frame & $\begin{array}{l}\text { According to the initial interpretation, the frame is "data structures for representing } \\
\text { stereotyped situations of visual perception" }\end{array}$ \\
\hline 5 & Logical-semantic & $\begin{array}{l}\text { This model allows capturing simultaneously the topic in general and each of its elements } \\
\text { individually; carrying out a comparative description of two phenomena, events, } \\
\text { establishing a causal relationship, identifying the main problem, and finding its solution }\end{array}$ \\
\hline 6 & Memory map & $\begin{array}{l}\text { The graphic expression of the multidimensional processes of thinking, a handy technique } \\
\text { to represent the process of thinking or structuring information }\end{array}$ \\
\hline
\end{tabular}

According to researchers (Sauer et al., 2001), using visualization of the educational process provides great opportunities in areas, such as:

- increasing motivation for learning, immersion in the topic, explanation, and consolidation of educational material;

- presenting the educational institution, specialty, teacher, textbook, and training course;

- presenting the results of scientific research of teachers, students, trainees, postgraduates, and doctoral students, as well as scientific laboratories, and teams.

Psychologists and philosophers pay attention not only to the role of visualization in the convenience of information perception but also emphasize its developing character in human mental processes. Thus, according to researchers (Horne, Thompson, 2008), the transformation of information into visual images leads to a deeper understanding, generalization, and effective perception of information by a person.

Researchers (Carr, 2003; Card, Mackinlay, Shneiderman, 1999) pay attention to the convenience, accessibility, and advantage of using visualization in the presentation of educational information, its developing role in maintaining the mental processes of the learner during the performance of educational activities, since visual images contribute to activation of the emotionalfigurative components of thinking, provide cognitive structuring of the knowledge content, cognitive modeling of the activity structure elements and object interaction processes, as well as the construction of new thought-forms and visual forms necessary for the study and understanding of the surrounding reality and universal values.

N.N. Manko (2007) writes that "making the meaning visible", visualization ensures the mobilization of the resources of the imaginative, logical, complex thinking of the learner, as well as the aesthetic, cultural, artistic potential, and other important traits and qualities of their personality.

In the study of E.A. Makarova (2010), it is noted that visualization allows actualizing various forms of thinking, such as visual-effective, figurative, associative, etc. It complements and develops auditory perception in verbal learning, activates various types of memory - verbal-logical, visualfigurative, emotional, etc. However, the most important thing is that visualization stimulates comprehension, generalization, clarification of perceived images, ensures the completeness and integrity of their perception.

V.L. Averbukh (2013) believes that the creation of multimedia models for knowledge representation should make it possible to make images of models as objects for logical thinking, as well as images of multimedia pictures that are used by imaginative thinking. Thus, the use of visualization technologies contributes to solving one of the main problems of contemporary education, namely, inspiring interest in learning and developing cognitive interest. 
The purpose of the present article is to develop a methodology for using operating system virtualization technologies during training in the discipline "Fundamentals of computer science".

Research hypothesis: the implementation of visualization in the educational process during distance learning of academic disciplines allows improving the preparation of students.

Research objectives:

- to find out the possibilities of using visualization to ensure the professional training of future specialists in the course of distance learning of academic disciplines;

- based on an empirical study, to assess the formedness of the cognitive and operational components of students' learning activities after conducting a formative experiment on the use of visualization.

- to consider the visualization tools used in distance learning of students.

The article consists of an introduction, a literature review, research methods, research results, their discussion, and conclusion.

\section{METHODS}

The research is based on the thesis that the use of visualization in professional training significantly affects its main characteristics, the pedagogical activity of teachers, and the distance learning work of students. Taking this into account, the purpose of using visualization is to modernize professional training, promptly updating its content, and providing equal access to participants in the educational process, regardless of their location, using high-quality educational and methodological materials created using visualization tools.

To achieve the set research goal, the following mix of methods was used.

- Theoretical analysis, comparison, generalization, and systematization, used to clarify the development status of the research problem in pedagogical theory and practice, to determine the content of the concepts of visualization, and visualization tools. This allowed finding out the possibilities of using visualization to ensure the professional training of future specialists in the course of distance learning of academic disciplines.

- Testing, interviewing, pedagogical observation, oral and written survey, analysis of the students' educational activities results, as well as expert evaluation, used to assess the average level of the formedness of the cognitive and operational components of the educational activities of students in the experimental and control groups after conducting a formative experiment on using visualization. To test the utilization efficiency of visualization tools, a pedagogical experiment was conducted.

To test the utilization efficiency of visualization tools, four groups, studied in the same course were involved. Given the fact that the students had not previously studied any disciplines related to the use of visualization tools, an entry-level assessment (before the experiment) was not conducted. The choice of these four study groups was because, at the beginning of the experiment, they had approximately the same average results of an educational activity (quality and academic performance) and the same number of students who had approximately the same characteristics in terms of age, gender, attitude to acquiring a future profession, and so on. $A$ control group (CG, $n=$ 52) was formed from two study groups. Students of this group studied mainly using conventional distance learning tools. The experimental group $(E G, n=53)$ also included students from two study groups. Training in the experimental group was carried out with the maximum possible use of visualization tools.

To assess the utilization efficiency of visualization tools during the pedagogical experiment, two criteria were used, namely, cognitive and operational, to diagnose the corresponding results of students' educational activities, such as knowledge, skills, and abilities, which are the main characteristics of readiness for professional activity. 
Indicators of the cognitive criterion were assessed by completing test assignments and an oral survey on a four-point scale with the entry of points in the electronic journal of academic performance.

The indicators of the operational criterion were assessed by performing learning activities on a four-point scale with the entry of points in an electronic journal.

\section{RESULTS}

Considering the theoretical foundations of the research, several visualization forms designed for distance learning of future specialists were developed and implemented in the educational process. The study focuses on those of them that are used for the training of students majoring in pedagogical specialties. The relevance of the implementation of the visualization forms presented in the results of the study is also due to the individual professional functions of future specialists, which determine the content of their training in the discipline "Pedagogical excellence".

To test the visualization efficiency, a pedagogical study was conducted, which lasted for a semester. During this period, students remotely studied the training course "Pedagogical excellence". In the course of the study, the use of visualization means was provided.

The visualization applying technique included several stages.

At the first stage, students were introduced to the content of the course "Pedagogical excellence", and the readiness of future specialists to work independently with the electronic learning resources (ELR) was determined. Using the interactive whiteboards or multimedia projectors, the features of the structure and work with ELR, as well as their didactic capabilities, were demonstrated.

At the second stage, during the distance classes, students received assignments, which involved the use of visualization. At this stage, the teacher acted as a tutor, who helped in finding the necessary information, that is, advised future specialists.

During the third stage, students used the didactic capabilities of several forms of visualization at once and solved problem situations.

At that, depending on the complexity of the material, the stages may be structured differently.

The results of the assessment of student's knowledge based on the indicators of cognitive and operational criteria for EG and CG after using visualization are presented in Tables 3 and 4.

The average score (Ks) and the integral criterion (Ki) was calculated by the following formula:

$$
\begin{aligned}
& K s=\left(k_{5} \bullet 5+k_{4} \bullet 4+k_{3} \cdot 3\right) /\left(k_{5}+k_{4}+k_{3}\right) ; \\
& K i=\left(k_{5}+k_{4}+k_{3}\right) / 3
\end{aligned}
$$

where $k_{5}, k_{4}, k_{3}$ are the numbers of students who respectively received excellent, good, and satisfactory grades.

Table 3. The results of the knowledge assessment of students in the CG according to the indicators of cognitive and operational criteria after the experimental application of visualization in distance learning

\begin{tabular}{|l|l|l|l|l|l|l|l|}
\hline Level & Excellent & \multicolumn{3}{l}{ Good } & Satisfactory & \multirow{2}{*}{ Average score } \\
\hline Criterion & Number & $\%$ & Number & $\%$ & Number & $\%$ & \\
\hline Cognitive & 12.0 & 6.90 & 32.0 & 18.39 & 34.0 & 19.54 & 3.72 \\
\hline Operational & 18.0 & 10.34 & 54.0 & 31.03 & 24.0 & 13.79 & 3.94 \\
\hline Total & 30.0 & 17.24 & 86.0 & 49.43 & 58.0 & 33.33 & \\
\hline Integral & 15.00 & 8.62 & 43.00 & 24.71 & 29.00 & 16.67 & 3.83 \\
\hline
\end{tabular}


Table 4. The results of the knowledge assessment of students in the EG according to the indicators of cognitive and operational criteria after the experimental application of visualization in distance learning

\begin{tabular}{|c|c|c|c|c|c|c|c|}
\hline \multirow{2}{*}{\begin{tabular}{|l|} 
Level \\
Criterion
\end{tabular}} & \multicolumn{2}{|l|}{ Excellent } & \multicolumn{2}{|l|}{ Good } & \multicolumn{2}{|c|}{ Satisfactory } & \multirow[t]{2}{*}{ Average score } \\
\hline & Number & $\%$ & Number & Number & $\%$ & Number & \\
\hline Cognitive & 26 & 14.9 & 39 & 22.41 & 9 & 5.17 & 4.23 \\
\hline Operational & 24 & 13.8 & 63 & 36.21 & 13 & 7.47 & 4.11 \\
\hline Total & 50 & 28.7 & 102 & 58.62 & 22 & 12.64 & \\
\hline Integral & 25.00 & 14.37 & 51.00 & 29.31 & 11.00 & 6.32 & 4.17 \\
\hline
\end{tabular}

The results of the evaluation of the average values of the cognitive and operational criteria for $E G$ and $C G$ after the experimental application of visualization in distance learning are shown in Figure 1.

Figure 1. The results of the evaluation of the average values of the cognitive and operational criteria for $E G$ and $C G$ after the experimental application of visualization

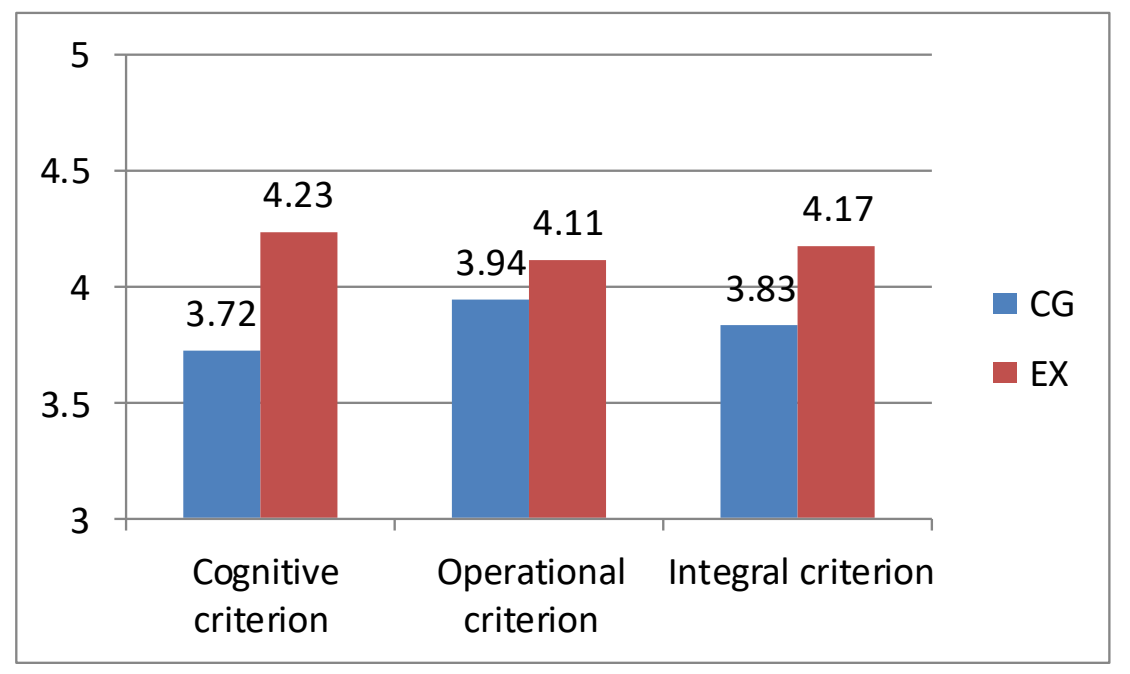

The results, clearly presented in Fig. 1, suggest that the students of the EG demonstrated higher results of educational activities in terms of the cognitive and operational components.

The number of students in the control and experimental groups was 174 each group. The students of the groups did not come across each other. The assessment was carried out on a fourpoint scale (the criteria did not overlap). The verification of the hypothesis regarding the reliability of the results obtained was carried out based on the Pearson criterion $\chi 2$. The calculations were performed in a Microsoft Excel spreadsheet processor. The corresponding results are shown in Table 5. 
Table 5. Calculation table to verify the hypotheses about the reliability of the results obtained based on the Pearson criterion $\chi^{2}$

\begin{tabular}{|c|c|c|c|}
\hline Performance rating scale & CG & EG & Calculation of $\chi^{2}$ criterion \\
\hline Excellent & $30(17.24 \%)$ & $50(28.74 \%)$ & 0.029 \\
\hline Good & $86(49.43 \%)$ & $102(58.62 \%)$ & 0.012 \\
\hline Satisfectory & $58(33.33 \%)$ & $22(12.54 \%)$ & 0.023 \\
\hline Total & $174(50.0 \%)$ & $174(50.0 \%)$ & 0.064 \\
\hline $\begin{array}{l}\text { Number } \\
\text { of degrees of freedom }\end{array}$ & & $x^{2}$ & Probability of getting a result \\
\hline 2 & & 0.064 & 0.968455 \\
\hline & & & 0.968455 \\
\hline & & & 0.995765 \\
\hline \multicolumn{3}{|c|}{$\begin{array}{l}\text { Critical } \chi^{2} \text { value } \\
\text { (maximum value for significance level) }\end{array}$} & Significance value \\
\hline & & 5.991 & 0.05 \\
\hline & & 5.991 & \\
\hline \multicolumn{4}{|c|}{ Testing the null hypothesis "the obtained values are valid» } \\
\hline \multicolumn{4}{|c|}{\begin{tabular}{|l|l|} 
Result: & No grounds for rejection \\
\end{tabular}} \\
\hline
\end{tabular}

The results of the calculations indicate that the probability that the data obtained are reliable is more than 0.96 . Therefore, one can conclude that the implementation of visualization in the educational process during distance learning of academic disciplines can improve the training quality of students.

\section{DISCUSSION}

Below are considered some of the visualization forms in the context of using them during the teaching of the distance course "Pedagogical excellence".

The flowchart type framework is characterized by an algorithmic approach that is used in computer science. It is recommended to use two types of flowcharts, which can be called algorithmic and logical. In the first case, using a flowchart, one can illustrate the algorithm for solving a certain pedagogical problem, using generally accepted notation. In the second case, the flowchart is used for the cognitive-graphical expression of the generalized structure of the learning certain topic. In this case, the training material can be represented in three forms: the basis of the theory, the core of the theory, and the applications of the theory.

Depending on the set didactic goal, the flowchart can be more or less unfolded. If the goal is to fully represent the core of the theory, for example, the logical-genetic relationship between the elements of the theory, then the flowchart does not need to be unfolded. If together with the core, the basis and applications of the theory are revealed in detail, then the flowchart is unfolded.

An important form of visualization is the supporting synopsis. This is a visual model of the educational material content of a certain module, section, or topic, built on special principles, in which the main essential concepts studied are briefly depicted, as well as graphical techniques can also be used to increase the mnemonic effect.

The next visualization form of educational information, in particular, during the teaching of the course "Pedagogical excellence" is a frame-based supporting diagram, which is an abstract image of standard stereotypical situations expressed in symbols, i.e. a rigid structure (frame), which contains empty windows as elements called slots which are repeatedly refilled with information. Both the supporting synopses and the frame diagrams allow compressing the text. The frame diagram compresses information tens and hundreds of times because it reflects a stereotypical situation (Turina, Sokolova, 2005). 
The educational information visualization forms include also cognitive maps or memory maps. The memory map allows combining visual and sensory associations in the form of interrelated ideas. Memory maps were used when planning or organizing activities. In this case, the main directions of future work are constantly within view, while the missing or additionally received information can be inserted at any time in the right place, without violating the structure of the synopsis. The memory map has its features: the basic idea is placed in the center, while the main topics that are related to the basic idea diverge from the center in the form of branches.

The visualization tools used in student distance learning are more considered below.

T.S. Skorochkina (2017) attributes to computer visualization tools those computer programs in which developers provided for the possibility of visual representation on the screen of abstract objects or processes, a compact form of their models (if necessary in different angles), in detail (with the possibility of demonstrating the internal relationships of the components, also hidden in the real world) and, most importantly, in the course of development (in time and spatial movement).

Besides, data visualization tools are divided into technical visualization tools (computer, pad, interactive whiteboard, multimedia projector, Internet, etc.) and software data visualization tools that allow the creation of ELR in the form of various objects, models, and forms. Among the software tools, scientists distinguish special-purpose and general-purpose software (Vladikov, Zelensky, Krupina, 2020), which force contemporary teachers of various disciplines to rethink the use of ICT in the educational process.

General software includes several modern software tools for data visualization. For example, software packages, such as MS Office, Google Sheets, Office 365, and others are most often used to create tables, graphs, diagrams, and structural logic diagrams.

One of the promising ways to visualize training data is to present them in the form of a mind map. Using maps drawn up according to certain rules, one can create, visualize, structure, and classify ideas, and visually present quite complex concepts and large amounts of information. Creating smart maps is possible employing software tools, such as XMind, MindMeister, MindMirPosylania, MindJet Mindmanager, iMind Map, etc.

Today, the most common software products for creating screencasts are Screencast-o-matic, Movenote, and a software Mobizen Screen Recorder for recording the screen of a mobile device, etc.

There are many different services on the Internet for creating infographics, in particular, Draw.io Pro, Piktochart, Easel.ly, Visual.ly, and Cacoo.

Educational films can be created using software tools, such as iSpring Suite, GoAnimate, SparkolPro, PowToon, Moovly, and Plotagon.

Software tools for creating multimedia presentations include MS PowerPoint, Apache OpenOffice Impress, Google Presentations, Prezi.com, etc.

Convenient network resources, such as ThingLink, Padlet, WikiWall, Glogster, and others can be used to create interactive virtual posters and whiteboards.

A.I. Azevich considers the study of interactive visual representations of abstract data as information visualization. Such histograms, trend graphs, flow diagrams, and tree diagrams relate to information visualization, and their design turns abstract concepts into visual information, which enhances the human cognition processes (Azevich, 2019).

Infographics is a graphical visual representation of data or knowledge, creating models of data representation in an easy-to-view and assimilate form, which helps to organize them correctly and simplify their perception. Infographics help to improve the perception of the data using graphic materials and to increase the ability of the human visual system to see models and processes (Shubina, 2020). 
The relevance of this area is evidenced by several online mass open courses on the Coursera platform, such as Data Visualization, Knight Center for Journalism, Introduction to Infographics and Data Visualization, as well as courses available on Linda.com educational portal, etc.

The analysis of scientific sources shows that infographic tools include a wide range of computer tools and Internet resources, namely: online resources for data visualization, tools for creating a word cloud, data visualization software, online infographic design tools, graphic editors, presentation programs, map creation tools, data sources and depositories, free storage of images, icons, mental map building tools and tools to visualize resumes (Zaslavsky, 2014; Grushevskaya, 2015).

One of the most convenient and easy free resources for creating infographics is Draw.io Pro resource, included in Google apps. Various templates of structures and forms are available on the site. Draw.io can be used also to create graphs and UML models. This resource supports the function of exporting ready-made diagrams, as well as the option of syncing with Google Drive. Due to the ability to attach it to a personal Google account, one can quickly search for the desired icons or backgrounds, as well as select the interface language.

Table 6 shows several common infographic tools.

Table 6. Common infographic tools

\begin{tabular}{|l|l|}
\hline Tool & Capabilities \\
\hline Inkscape & Free illustration editing software \\
\hline Adobe Illustrator & Professional illustration editing tool \\
\hline Piktochart & Allows users to create infographics using 400 free templates \\
\hline Gapminder & $\begin{array}{l}\text { Online and offline versions of the software for interactive visualization of indicators of global } \\
\text { development statistics of countries and continents }\end{array}$ \\
\hline Tableau & $\begin{array}{l}\text { Five data visualization products: Tableau Desktop, Tableau Server, Tableau Online, Tableau } \\
\text { Reader, Tableau Public; the latter two products are for free use }\end{array}$ \\
\hline Wordle & Creating a word cloud from the terms of an article, book, or website \\
\hline Visual.ly & Website for viewing and sharing infographics; best practices of its application \\
\hline ResumUp & Presenting a resume as an infographic \\
\hline
\end{tabular}

Another area of application of multimedia data visualization tools is the creation of educational films using programs for recording video from a screen or mobile device computer (Hall, Obregon, 2002). The iSpring Suite service is especially interesting. This application is distinguished by its simplicity and clarity. It allows correctly recording instructions, lecture fragments, reviews of the training program operation, refer and comment on examples for completing tasks, demonstrating the work on the computer screen, and accompanying it with voice comments.

The iSpring Suite application extends the functionality of the PowerPoint. The main features of the application are recording the computer screen for creating educational videos; combining presentation slides; developing and designing tests and surveys; creating dialogs; synchronizing audio and video files; creating interactive reference books. The application can be integrated with PowerPoint as an individual tab.

Multimedia presentations are a set of slides that can contain text, graphical objects, drawings, and the like. A presentation can contain audio, video, and animation. Multimedia effects of the presentation allow focusing the audience's attention on the main point and contribute to a better memorization of the educational material. In the authors' opinion, the most convenient and 
accessible software tools for creating multimedia presentations for university teachers are Apache OpenOffice Impress and Google Presentations.

During the explanation of the educational material, the teacher can also use graphic data and video clips to stimulate cognitive interest and motivation for learning, as well as computer learning environments to illustrate the phenomena being studied, and so on. In the presentation, one can use various special effects which attract the attention of students and provide an opportunity to focus on the most significant points in the course of the explanation.

For students not to search for the necessary information on different sites, it is convenient to collect multimedia educational products on a specific topic in one place. Services that help to place multimedia data on a single online whiteboard or wall come to the rescue.

Interactive online whiteboards or walls appeared in 2006-2007 and now continue to gain popularity among teachers. An interactive online whiteboard (wall) is a learning tool that allows combining text, images, videos, and audios in an interactive form.

Today, among the most common software products for interactive whiteboards, is RealtimeBoard, which is used for developing ELR, project management, holding brainstorming, organizing educational courses, and the like. RealtimeBoard is very suitable for joint work. The system of comments-mini chats allows leaving notes attached to any element. Due to the integration with Google Drive, one can easily visually work with documents and edit them. The result of the work can be saved as an image or PDF file. The whiteboard can be saved also as a presentation.

\section{CONCLUSION}

In the context of informatization of all spheres of human activity, the rapid development of ICTы and their intense implementation into the educational process of universities, the creation of ELR using software tools for data visualization provides their representation in a collapsed and visual form that is convenient for perception and comprehending, deeper understanding, generalization and effective perception by a person. Visualization, as one of the effective methods of intensifying the educational process, provides the structuring of knowledge by compressing the educational material and displaying it in a brief form.

Analyzing the experience of using visualization in the educational process, one can conclude that the processes of dissemination of visualization technologies occur rapidly. This necessitates conducting research aimed at analyzing the effect of visualization on the effectiveness of teaching, as well as developing practice-oriented pedagogical technologies for their effective use in the educational process, and creating appropriate educational and methodological support.

Several areas of visualization can be distinguished in educational practice, such as visualizing educational content (imaginative representation of new educational information, consolidation of educational material, as well as its systematization using visualization); presenting of the teacher, educational program, educational institution; creating knowledge maps of the certain subject area to transform educational content into convenient visual constructs; conducting joint activities of the teacher and the listener or student aiming at infographic representation of a distance course, network project, etc.

Visualization of educational material in the discipline "Pedagogical excellence" teaches students to transform oral and written information into a visual form, which develops their professional thinking due to the systematization and allocation of the most significant, essential elements of the educational material. Thus, the main tasks of information visualization in the course of teaching the discipline are to draw attention to the message, increase the level of knowledge assimilation, and speed up knowledge perception.

The content of the academic discipline and the degree of abstraction of its basic concepts affect the choice of the visualization form. Also, the choice depends on the specifics of the academic 
discipline, its structural and logical scheme, and the level of study. In any case, the teacher finds the visual model form most acceptable for themself and their subject.

Generalization and analysis of the results of using visualization tools indicate the feasibility of their implementation in the educational process. This is confirmed by the higher results shown by the students of the experimental group in terms of cognitive and operational criteria. The calculations on the reliability of the results obtained, carried out according to the Pearson criterion $\chi 2$, showed that the reliability was more than 0.96 .

Thus, the results of the study confirmed the hypothesis about the effectiveness and expediency of using visualization tools to improve distance learning for students.

Therefore, using modern visualization technologies in the educational process creates prerequisites for improving the quality and effectiveness of training. Visualization is a key factor in improving the effectiveness of the educational process, which allows solving a set of pedagogical problems, namely, making the complex educational material of academic disciplines understandable, accessible to awareness, without reducing the level of its scientific value; attracting and developing students' interest in studying subjects that are traditionally considered rather complicated; creating conditions for the informal assimilation of the content of training by students, for the acquisition of deep, systematic knowledge, and so on. At the same time, visualization is a powerful didactic tool, whose application should be motivated, pedagogically appropriate, and supported methodically.

The conducted study does not exhaust all aspects of the problem under study. The problematic issues of improving the quality of professional training of future specialists through the development and use of virtual and augmented reality tools require further consideration.

Authors' Contributions: Anatoly Nikolaevish Andreev: designed the study, prepared the plan, wrote the first draft of the manuscript and edited the final ver. Olga Viktorovna Emtseva: designed the study, prepared the plan, wrote the first draft of the manuscript and edited the final ver. Ekaterina Sergeevna Babkina: designed the study, prepared the plan, wrote the first draft of the manuscript and edited the final ver. Valeriy Nikolaevich Dolzhenkov: designed the study, prepared the plan, wrote the first draft of the manuscript and edited the final ver. Nina Valentinovna Kudryashova: designed the study, prepared the plan, wrote the first draft of the manuscript and edited the final ver. All authors have read and approved the final version of the manuscript.

Ethics Approval: Not applicable.

Acknowledgments: Not applicable.

\section{REFERENCES}

Abramova, N.A., Voronina, T.A., Portsev, R.Yu. (2010). O metodah podderzhki postroeniya i verifikacii kognitivnyh kart s primeneniem idej kognitivnoj grafiki [On methods of supporting the construction and verification of cognitive maps using the ideas of cognitive graphics], 30(1), 411-430.

Averbukh, V.L. (2013). Semiotika i osnovaniya teorii komp'yuternoj vizualizacii [Semiotics and foundations of the computer visualization theory]. Philosophical Problems of Information Technologies and Cyberspace, 1, 26-41.

Azevich, A.I. (2019). Servisy vizualizacii dannyh: priemy i resheniya [Data visualization services: Techniques and solutions]. Bulletin of the Moscow State Pedagogical University. Series: Informatics and informatization of education, 1(47), 13-19.

Bratash, V.S., Galaktionova, T.G. (2020). Sovremennyj etap transformacii uchebnogo teksta: dominirovanie vizual'nogo komponenta [The modern stage of the educational text transformation: The dominance of the visual component]. Bulletin of the Moscow City Pedagogical University. Series: Pedagogy and Psychology, 1(51), 107-117.

Card, S.K., Mackinlay, J.D., Shneiderman, B. (1999). Readings in information visualization: Using vision to think. San Francisco: Morgan Kaufmann Publishers Inc.

Carr, C.S. (2003). Visualizing argumentation: Software tools for collaborative and educational sense-making, using computer-supported argument visualization to teach legal argumentation. Springer-Verlag, pp. 75-96. 
Dodero, J.M., Val, Á.M., del Torres, J. (2010). An extensible approach to visually editing adaptive learning activities and designs based on services. Journal of Visual Languages and Computing, 21(6), 332-346.

Gilbert, J. (2005). Visualization: a metacognitive skill in science and science education. Visualization in Science Education, Springer. https://doi.org/10.1007/1-4020-3613-2_2

Glizburg, V.I., Zykova, I.F. (2016). Vizualizaciya kak sredstvo formirovaniya metapredmetnyh znanij [Visualization as a means of forming meta subject knowledge] [Text]. Bulletin of the Moscow State Pedagogical University (MSPU), Series: Pedagogy and Psychology, 3(37), 65-73.

Grushevskaya, V.Yu. (2015). Principy ispol'zovaniya onlajn-redaktorov infografiki [Principles of using online infographic editors]. Pedagogical Education in Russia, 7, 58-63.

Hall, K.W., Obregon, R. (2002). Applications and tools for design and visualization. The Technology Teacher, 61(7), 711.

Horne, M., Thompson, E. (2008). The role of virtual reality in built environment education. Journal for Education in the Built Environment, 3(1), 5-24.

Kukhta, M.S. (2004). Vospriyatie vizual'noj informacii: filosofiya processa [Perception of visual information: Philosophy of the process]. Tomsk: Tomsk State Pedagogical University (TSPU) Publishing House.

Lopuga, V.F. (2012). Primenenie intellekt-kart v obrazovatel'nom processe [Application of mind maps in the educational process]. Pedagogical Education in the Altai, 1, 121-126.

Makarova, E.A. (2010). Vizualizaciya kak introekciya smysloobrazov v mental'noe prostranstvo lichnosti: monografiya [Visualization as an introjection of semantic images into the mental space of the personality: Monograph]. Moscow: Sputnik.

Manko, N.N. (2007). Kognitivnaya vizualizaciya didakticheskih ob"ektov: monografiya [Cognitive visualization of didactic objects: Monograph]. Ufa.

Manko, N.N. (2009). Kognitivnaya vizualizaciya pedagogicheskih ob"ektov v sovremennyh tekhnologiyah obucheniya [Cognitive visualization of pedagogical objects in modern teaching technologies]. Education and Science, 8, 10-30.

Mathai, S., Ramadas, J. (2009). Visuals and visualization of human body systems. International Journal of Science Education, 31(3), 439-458.

Ovchinnikova, K.R. (2015). Rol' informacionnyh tekhnologij v predstavlenii predmetnoj informacii v vuze [The role of information technologies in the presentation of subject information at the university]. Bulletin of the Peoples ' Friendship University of Russia (RUDN), Series: Informatization of Education, 3, 36-44.

Pervushina, N.A. (2013). Uspeshnost' vizualizacii informacii v processe obucheniya [The success of information visualization in the learning process]. Pedagogical Review, 2(2), 30-35.

Rabadanova, R.S., Bogatyreva, S.N., Artemieva, S.I., Aralova, E.V., Polozhentseva, I.V., Pisarevsky, K.L. (2020). Key features of human nutrition behavior. Revista Inclusiones, 7(S1-1), 170-181.

Roem, D. (2012). Vizual'noe myshlenie. Kak «prodavat'» svoi idei pri pomoshchi vizual'nyh obrazov [Visual thinking. How to push your ideas using visual images]. Moscow: Mann, Ivanov, Ferber.

Rodrigues, B. M., Santos, J. E. B., \& Vasconcelos, C. A. (2020). Conceptions of undergraduate students in Chemistry on the use of interactive interfaces in and for the activities developed in the distance course. Journal of Research and Knowledge Spreading, 1(1), e11649. http

Sauer, F., Khamene, A., Bascle, B., Schimmang, L., Wenzel, F., Vogt, S. (2001). Augmented reality visualization of ultrasound images: System description, calibration, and features. IEEE and ACM International Symposium on Augmented Reality, pp. 30-39.

Selevko, G.K. (1998). Sovremennye obrazovatel'nye tekhnologii [Contemporary educational technologies]. Moscow: Popular Education.

Shubina, A.A. (2020). Infografika kak sovremennaya obrazovatel'naya tekhnologiya. Etapy ee razrabotki [Infographics as modern educational technology. Stages of its development]. A Young Scientist, 23(313), 665-667.

Sousa, J. M. (2016). Repensar o Currículo como Emancipador. Revista Tempos e Espaços em Educação, 9(18), 111-120.

Skorochkina, T.S. (2017). Informacionnye tekhnologii vizualizacii biznes-informacii [Information technologies of business information visualization]. Moscow: Financial University. 
Turina, R.V., Sokolova, E.E. (2005). Frejmovoe predstavlenie znanij: monografiya [Frame representation of knowledge: Monograph]. Moscow: Public education.

Vinichenko, M.V., Chulanova, O.L., Oseev, A.A., Bogdan, E.S., Makushkin, S.A., Grishan, M.A. (2018). Interaction of the higher education and key employer for the formation of the actual profile of the competencies of graduates of engineering directions. Modern Journal of Language Teaching Methods, 8(5), 393-403.

Vladikov, A.A., Zelensky, E.E., Krupina, V.V. (2020). Sovremennye sredstva vizualizacii dannyh [Modern means of data visualization]. Modern Science, 4-3, 392-406.

Wang, Ya., Katkhanova, Yu.F. (2020). Tendenciya razvitiya vizualizacii informacii v obrazovatel'noj srede [The trend of information visualization development in the educational environment]. Teacher: the 21st Century, 1(1), $154-158$.

Zaslavskaya, O.Yu. (2019). Ispol'zovanie instrumentov vizualizacii v processe obucheniya studentov pedagogicheskogo vuza [Using visualization tools in the course of teaching students of a pedagogical university]. Bulletin of the Moscow State Pedagogical University. Series: Informatics and Informatization of Education, 3(49), 17-23.

Zaslavsky, A.A. (2014). Effektivnye priemy ispol'zovaniya infografiki kak sredstva individualizacii obucheniya [Effective methods of using infographics as a means of individualization of training]. Bulletin of the Moscow State Pedagogical University. Series: Informatics and Informatization of Education, 3(29), 94-98.

Zelyazny, D. (2012). Govori na yazyke diagramm: posobie po vizual'nym kommunikaciyam [Speak in the language of diagrams: A manual on visual communications]. Moscow: Mann, Ivanov and Ferber.

Received: 31 April 2021 | Accepted: 2 June 2021 | Published: 14 July 2021

This is an Open Access article distributed under the terms of the Creative Commons Attribution License, which permits unrestricted use, distribution, and reproduction in any medium, provided the original work is properly cited. 